\title{
Trade, Extent of the Market, and Economic Growth 1960-1996
}

\author{
by \\ Francisco Alcalá \\ University of Murcia \\ Antonio Ciccone \\ Universitat Pompeu Fabra
}

December 2003 (First version: February 2003)

\begin{abstract}
We find that trade and domestic market size are robust determinants of economic growth over the 1960-1996 period when trade openness is measured as the US dollar value of imports and exports relative to GDP in PPP US\$ ("real openness"). When trade openness is measured as the US dollar value of imports and exports relative to GDP in exchange rate US\$ ("nominal openness") however, trade and the size of domestic markets are often non-robust determinants of growth. We argue that real openness is the more appropriate measure of trade and that our empirical results should be seen as evidence in favor of the extent-of-the-market hypothesis (JEL F43, O40).
\end{abstract}

Keywords: Extent of the market, Institutions, Growth.

We thank Alberto Alesina, Marco Maffezzoli, and seminar participants at the Bank of Italy and Bocconi University for their helpful comments. We also thank Rita Almeida, Marek Jarocinski, and Raffaella Sadun for excellent research assistance. We are especially grateful to Jose Garcia-Montalvo and Marek Jarocinski for helping us with their econometric expertise. Ciccone gratefully acknowledges financial support from the Centre de Recerca en Economia Internacional (CREI) at UPF as well as from the Spanish Ministry of Science and Technology through DGICYT grant PB98-1066 and the European Commission through RTN grants HPRN-CT-2000-00061 and HPRNCT-2000-00072. Contact address: Antonio Ciccone, Department of Economics and Business, Universitat Pompeu Fabra, C. Ramon Trias Fargas 25-27, 08005 Barcelona, Spain. Email: antonio.ciccone@upf.edu 


\section{Introduction}

The effect of trade and extent of the market on growth is a recurring issue in economics. Raised by Adam Smith more than two centuries ago, it is still debated today. For example, empirical work by Levine and Renelt (1992), Sala-i-Martin (1997a,b), and Masters and McMillan (2001) finds that trade and the extent of the domestic market are not robust determinants of economic growth for the 1960-1990 period. But Ades and Glaeser (1999), Frankel and Romer (1999), Alesina, Spolaore, and Wacziarg (2000, 2003), and Frankel and Rose (2002) argue that access to larger markets fostered economic growth over the same period. Our objective here is to examine whether trade and extent of the market were robust determinants of cross-country economic growth for the 1960-1996 period.

One of the challenges in answering this question is that trade is endogenous and may be driven by economic growth. Identifying the effect of trade on economic growth therefore requires an approach that can disentangle the two directions of causality. This can be done by using instruments for trade, an approach pursued by Ades and Glaeser (1999), Frankel and Romer (1999), Alesina, Spolaore, and Wacziarg (2000), and Frankel and Rose (2002) for example. We will follow their lead and use geographic characteristics of countries to identify the effect of trade on economic growth.

When determining the effect of trade and extent of the market on economic growth it is necessary to account for other factors that may explain growth. One of the most important variables is institutional quality, which has been shown to be positively correlated with growth by Knack and Keefer (1995), Knack (1996), and Keefer and Knack (1997)). Sala-iMartin $(1997 a, b)$ has demonstrated that this correlation is robust to the inclusion of many other explanatory variables. Moreover, Hall and Jones (1999) and Acemoglu, Johnson, and Robinson (2001) have shown, using instruments for institutional quality, that there is a positive causal effect running from institutions to productivity. We therefore always include institutional quality in our empirical analysis and address the potential endogeneity problem (and the measurement error problem) following the work of HJ and AJR. 
A very recent, rapidly growing econometric literature emphasizes various important statistical problems that may arise when instrumental-variables estimators are based on low-quality instruments (e.g. Stock and Staiger (1997), Kleibergen (2001, 2002), Moreira (2003), Hahn and Hausman (2003)). Low-quality (weak) instruments (among other things) invalidate the standard limiting distributions of instrumental-variables estimators, which implies that hypotheses cannot be tested using standard statistics. Following this literature, we implement test statistics that are asymptotically valid in the presence of weak instruments (Kleibergen (2001, 2002), and Moreira (2003)). Moreover, we also use estimators that have been shown to be more robust to weak-instrument problems than twostage least-squares (Stock, Wright, and Yogo (2002), Hahn and Hausman (2003)).

While there is an emerging consensus on institutional quality as a key determinant of economic performance, there seems to be no agreement on which other variables should always be accounted for in growth regressions. This introduces a difficulty for empirical work as the list of candidates is by now rather long. We focus on those explanatory variables that have been shown to be most robust in the empirical work of Sala-i-Martin (1997a,b) and Doppelhofer, Miller, and Sala-i-Martin (2003).

Trade openness can be measured in different ways. For example, Ades and Glaeser (1999), Frankel and Romer (1999), Alesina, Spolaore, and Wacziarg (2000), and Frankel and Rose (2002) measure trade openness using the US dollar value of imports and exports relative to GDP in exchange rate US\$ (which we refer to as nominal openness). This very natural measure of trade openness is not without potential drawbacks. We therefore consider two alternatives. Our first alternative measure is the US dollar value of imports and exports relative to GDP in PPP US\$ (which we refer to as real openness). Our second alternative measure of trade openness is real openness predicted by the geographic characteristics of countries (which has the advantage of being exogenous but the disadvantage of capturing only a part of trade openness).

To see one of the potential drawbacks of nominal openness compared to real openness as a measure of trade openness, consider two countries that are identical in terms of the quantities of goods produced and traded. But suppose that one of the two countries has a higher relative price of non-traded goods (maybe because of the Balassa-Samuelson effect 
associated with a higher level of total factor productivity). In this case the two countries have different values of nominal trade openness, although they trade the same quantities by construction. Using the value of imports and exports relative to PPP GDP (real openness) as the measure of trade openness yields that both countries are equally open. This potential drawback of using GDP in exchange rate US\$ to normalize determinants of cross-country growth is why explanatory variables like private and public investment, the size of government, government consumption, and many others are always measured relative to GDP in PPP US\$ (e.g. Sala-i-Martin (1997a,b)).

To see a second, related potential drawback of nominal openness, suppose that the higher relative price of non-traded goods in one of the aforementioned countries is in fact driven by the Balassa-Samuelson effect. In this case the country with higher average labor productivity will have lower nominal openness. ${ }^{1}$ This could lead (a simple minded) observer to conclude that trade may be bad for productivity (although the two countries trade the same quantities by construction).

A third potential drawback of nominal trade openness is discussed in Alcalá and Ciccone (2003). There it is shown that nominal openness may be decreasing in the degree of specialization in a model with increasing returns to specialization (motivated by the work of Helpman (1981) and Krugman (1981)). The reason is that specialization may increase productivity relatively more in the traded-goods sector and therefore translate into higher non-traded goods prices, which may reduce nominal openness. Hence, nominal openness may be negatively correlated with average labor productivity although trade, by allowing for specialization, increases productivity. ${ }^{2} \mathrm{AC}$ use the same model to show that real openness is monotonically increasing in the degree of specialization.

Our empirical results on the effect of trade and extent of the market on economic growth 1960-1996 indicate that the extent of the market is often a non-robust determinant

1 This is because the country with higher total factor productivity, which due to the Balassa-Samuelson effect has higher non-traded goods prices and lower nominal openness, requires less labor to produce the same quantity of goods as the country with lower total factor productivity.

${ }^{2} \mathrm{AC}$ also show that the drawbacks of nominal openness persist even if trade is instrumented. This is because exogenous variables raising trade and increasing the degree of specialization will increase the price level. 
of economic growth when nominal openness is used to measure trade. But when we measure trade using real openness or geography-fitted real openness, the effect of trade and extent of the market on growth is robust to the inclusion of institutional quality and the controls emphasized by Doppelhofer, Miller, and Sala-i-Martin (2003). Moreover, trade matters more in countries with smaller domestic markets, confirming the hypothesis of Alesina, Spolaore, and Wacziarg (2000). This interaction effect between trade and domestic market size turns out to be crucial for testing the extent-of-the-market hypothesis: eliminating it usually results in both trade and domestic market size being insignificant determinants of 1960-1996 growth rates.

The remainder of the paper is organized in the following way. Section 2 discusses the most closely related literature. Section 3 presents the empirical framework. Section 4 explains the data sources. Section 5 discusses the empirical results. Section 6 concludes.

\section{Related Literature}

The partial correlation between nominal openness and economic growth in a cross-country context is analyzed in Levine and Renelt (1992) and Harrison (1996). These studies tend to find a positive correlation but LR argue that this correlation is not robust to the inclusion of other variables explaining economic growth. Barro and Sala-i-Martin (1995) and Sala-iMartin (1997a,b) include working-age population as a control for domestic market size in their empirical work on the determinants of economic growth and find that this variable is not robust.

A more recent analysis of the effect of trade and extent of the market on economic growth can be found in Ades and Glaeser (1999), Frankel and Romer (1999), Alesina, Spolaore, and Wacziarg (2000), Masters and McMillan (2001), and Frankel and Rose (2002). ${ }^{3}$ These studies have in common that they use nominal openness as a trade measure and that they consider trade and some measure of domestic size as joint determinants of economic growth. The basic idea is that the extent of the market depends on both variables. Possible reverse causation from economic growth to openness is addressed using geography-based instruments for trade in AG, Frankel\&Romer, ASW, and Frankel\&Rose.

\footnotetext{
${ }^{3}$ Wacziarg (2001) examines the growth effects of policy-driven trade flows.
} 
MM address this issue by using nominal openness at the beginning of the sample period as their trade measure. The main difference between these studies is that AG, Frankel\&Romer, ASW, and Frankel\&Rose find support for the extent-of-the market hypothesis, while MM argue that the evidence for this hypothesis is not robust. ${ }^{4}$

The study most closely related to our empirical work is Alesina, Spolaore, and Wacziarg (2000) (for extensions and further empirical results see Spolaore and Wacziarg (2002) as well as Alesina, Spolaore, and Wacziarg (2003)). We follow their lead in using population size as a measure of domestic market size and, crucially, in allowing trade openness to have a stronger effect in countries with a smaller domestic market. ${ }^{5}$ Without the interaction effect between domestic market size and trade, both domestic market size and trade usually turn insignificant as determinants of 1960-1996 growth rates. The main difference between Alesina, Spolaore, and Wacziarg (2000, 2003) (and Spolaore and Wacziarg (2002)) and our work is that, in addition to using nominal openness as a trade measure, we also employ two alternative measures, real openness and geography-fitted real openness. ${ }^{6}$ A second difference with ASW is that we account for institutional quality as a possible determinant of cross-country growth. Moreover, we draw on the work of Sala-iMartin (1997a,b)) and especially Doppelhofer, Miller, and Sala-i-Martin (2003) to identify the most important "other" control variables to be included in the empirical analysis.

Frankel and Rose (2002) also account for institutional quality when analyzing the effect of trade and domestic market size on economic growth. The main differences between their study and our work are that they only try no minal openness as a trade openness measure; that they do not follow Alesina Spolaore, and Wacziarg (2000) in including an interaction effect between trade and domestic market size; and that they do not use instruments for institutional quality.

\footnotetext{
${ }^{4}$ They find evidence for the extent-of-the-market hypothesis in the sub-sample of tropical countries however.

${ }^{5}$ Ades and Glaeser (1999) also allow for this possibility but measure domestic market size using GDP per capita.

${ }^{6}$ The only paper using real openness as a possible determinant of economic growth we are aware of is Dollar and Kraay (2003), who apply a panel-data approach in the spirit of Caselli, Esquivel, and Lefort (1996) to decadal growth rates for the period 1970-2000.
} 
Our geography-fitted real openness trade measure is constructed following the work of Frankel and Romer (1999). They use a gravity-equation framework to determine the part of bilateral trade-shares that can be explained by geographic characteristics and population. The geography-fitted bilateral trade shares for each country with the rest of the world are then summed up to obtain a measure of geography-fitted real openness (vis-à-vis the rest of the world). We employ geography-fitted real openness both as a (exogenous) measure of trade openness and as an instrument to estimate the effect of trade on economic growth using an instrumental-variables approach. We also use instruments for institutional quality, following the work of Hall and Jones (1999) and Acemoglu, Johnson, and Robinson (2001).

\section{Estimating Equation}

Following the work on the determinants of economic growth by Barro (1991), Mankiw, Romer, and Weil (1992), and Alesina, Spolaore and Wacziarg (2000), we estimate the following equation

$$
\begin{aligned}
& \frac{\log y_{c, 1996}-\log y_{c 1960}}{36} * 100 \\
& =\beta_{0}+\beta_{1} \text { TROpen }_{c}+\beta_{2} \text { DMSize }_{c}+\beta_{3} \text { TROpen }_{c} * \text { DMSize }_{c}+\beta_{4} \text { IQual }_{c} \\
& +\beta_{5} X_{c}+\beta_{6} \log y_{c 1960}
\end{aligned}
$$

where $\left(\log y_{c, 1996}-\log y_{c 1960}\right) * 100 / 36$ is the average growth rate of income per capita 1960-1996; TROpen denotes a measure of trade openness; DMSize a measure of domestic market size; IQual a measure of institutional quality; $X$ a series of control variables; and

$\log y_{1960}$ the log of initial income per capita. The basic objective of this estimating equation is to see whether countries with access to larger markets grew more over the 1960-1996 period, conditional on their initial income per capita and other factors. We follow Alesina, Spolaore, and Wacziarg (2000) and Spolaore and Wacziarg (2002) in allowing for an interaction effect between trade openness and domestic market size; including this 
interaction term permits trade to matter more (or less) in countries that have smaller domestic markets.

We try several measures of trade openness and institutional quality in equation (1). In particular, we use three measures of trade openness, imports plus exports in US\$ divided by GDP in exchange rate US\$ (NOpen), imports plus exports in US\$ divided by GDP in PPP US\$ (ROpen), and geography-fitted real openness.

\section{Data}

The data on PPP GDP per capita, population, and nominal as well as real openness are taken from the PWT 6.1 by Heston, Summers, and Aten (2002). The measures of nominal and real openness used in equation (1) are averaged over the 1960-1996 period (we use 1996 as the final year because this is the last benchmark year). The data on institutional quality is taken from Hall and Jones (1999) and Kaufmann, Kraay, and Zoido-Lobatón (2002). HJ construct a measure of government anti-diversion policies using late-1980s data from the International Country Risk Guide concentrating, like Knack and Keefer (1995), on five of the twenty-four categories provided. KKZL construct a measure of rule of law using a large number of late-1990s governance indicators, which they reduce to a single rule-of-law index using an unobserved components methodology. ${ }^{7}$ The set $X$ of growth controls is taken from Sala-i-Martin (1997a,b) and Doppelhofer, Miller, and Sala-i-Martin (2003). These papers propose different methodologies to determine the most robust explanatory variables for growth among a large set of candidates.

Nominal openness and real openness are instrumented using the approach of Frankel and Romer (1999). FR construct their instrument in two steps. The first step consists of estimating a gravity equation for 1985 bilateral trade shares (relative to PPP GDP) that uses countries' geographic characteristics and population only as explanatory variables (the estimating equation does not include measures of productivity or income), i.e.

\footnotetext{
${ }^{7}$ This index is available for various years. We take the average over the available years for each country.
} 


$$
\begin{aligned}
& \log \left(\frac{\tau_{i j}}{P P P G D P_{i}}\right)=\alpha_{0}+\alpha_{1} \log \text { Dist }_{i j}+\alpha_{2} \log \text { Pop }_{i}+\alpha_{3} \log \text { Area }_{i}+\alpha_{4} \log \text { Pop }_{j} \\
& +\alpha_{5} \log \text { Area }_{j}+\alpha_{6}\left(L d l_{i}+L d l_{j}\right)+\alpha_{7} C b_{i j}+\alpha_{8} C b_{i j} \log \text { Dist }_{i j}+\alpha_{9} C b_{i j} \log \text { Pop }_{i} \\
& +\alpha_{10} C b_{i j} \log \text { Area }_{i}+\alpha_{11} C b_{i j} \log \text { Pop }_{j}+\alpha_{12} C b_{i j} \log \text { Area }_{i}+\alpha_{13} C b_{i j}\left(L d l_{i}+L d l_{j}\right)+v_{i j}
\end{aligned}
$$

where $\tau_{i j}$ denotes exports of country $i$ to country $j$ plus exports from $j$ to $i$; Dist $t_{i j}$ is the distance between the two countries; Pop $_{i}$, Pop $_{j}$ denote the population of the two countries; Area $_{i}$, Area $_{j}$ denote the area of the two countries; $L d l_{i}, L d l_{j}$ are dummies indicating whether countries $i, j$ are landlocked; $C b_{i j}$ is a dummy indicating whether or not the two countries have a common border; and $v_{i j}$ summarizes the variation in bilateral trade shares no captured by our empirical approach. The common border dummy is included by itself in the regression as well as interacted with other explanatory variables to capture trade between neighboring countries more accurately. The ordinary least-squares estimates of the $\alpha-$ coefficients can be used to determine the predicted value of the bilateral trade share for each pair of countries for which there is data on the right-hand-side variables (even if we do not have any bilateral trade data for those countries). The second step of the FR procedure consists of aggregating the predicted value of bilateral trade shares for each country with all other countries to obtain geography-fitted real openness (TRgeofit)

$$
\text { TRgeofit }_{i} \equiv \sum_{j} \exp \left(\text { Predicted Value of } \log \left(\frac{\tau_{i j}}{P P P G D P_{i}}\right)\right)
$$

We use the FR approach exactly. The only difference is that we employ more data on bilateral trade shares to estimate the gravity-equation. Our 1985 bilateral trade data, taken from different Yearbook issues of the Direction of Trade Statistics published by the International Monetary Fund, consists of 10569 observations (FR work with 3969 observations). Alcalá and Ciccone (2003) show that the additional bilateral-trade data translates into a considerable improvement in predicting nominal and real openness. We also adapt the FR procedure to construct geography-fitted nominal openness (TRnomgeofit), which we use as an instrument when we use nominal openness as our trade 
openness measure. Geography-fitted nominal openness is constructed exactly as geography-fitted real openness, only that trade share on the left-hand-side variable of (2) is relative to GDP in exchange rate US\$.

Both measures of institutional quality used in equation (1) are only available towards the end of the sample period and are therefore endogenous. Moreover, they are probably noisy reflections of true institutional quality. To address possible endogeneity and measurement-error problems we therefore use the instruments for institutional quality suggested by Hall and Jones (1999) and Acemoglu, Johnson, and Robinson (2001). HJ instrument institutional quality using the fraction of the population speaking English at birth (EngL), the fraction of the population speaking one of the five primary European languages at birth (EuroL), and the distance from the equator (AbsLati). They argue, based on historical considerations, that these variables are correlated with past European influence and therefore with the transmission of the European institutional framework. (They check the validity of distance from the equator as an instrument by testing the hypothesis that distance from the equator does not affect productivity once institutional quality is accounted for and find that this hypothesis cannot be rejected at conventional significance levels.) AJR suggest settler mortality between the $18^{\text {th }}$ and $19^{\text {th }}$ century as an instrument for institutional quality in a sample of former colonies. Their argument, also based on historical considerations, is that institutions permitting short-run extraction of income from colonies were more likely when survival conditions for long-term European settlements were unfavorable. Following the argument of AJR, we also use the share of inhabitants of European origin in 1900 as an instrument for institutional quality in former colonies (this variable is also taken from AJR).

\section{Results}

\section{Least-Squares Results}

Table 1 contains the results of estimating the growth regression in (1) without any extentof-the-market variables. The sample size (just below 100) is determined by the number of countries where all necessary data are available. Column (1) controls for initial income per capita and the five most robust growth controls of Doppelhofer, Miller, and Sala-i-Martin 
(2003). The method of estimation is least squares with robust standard errors (homoskedasticity can be rejected at the 5-percent level). It can be seen that all variables are significant at the 5-percent level and that the regression captures 66 percent of the variation in growth rates. Columns (2) and (3) add the GADP and RLAW institutional controls respectively, and both turn out to be highly significant. These regressions capture close to 70 percent of the variation in growth rates. Column (4) controls for initial income per capita and the eleven robust growth controls of Doppelhofer, Miller, and Sala-i-Martin (2003). All controls, except the fraction of Protestants, are significant at the 10-percent level (and all but three are significant at the 5-percent level). The regression captures 76 percent of the variation in growth rates. Columns (5) and (6) add the GADP and RLAW institutional quality measure respectively, and both turn out to be highly significant. The regressions now capture just under 80 percent of the variation in growth rates.

Table 2 adds extent-of-the-market variables to the growth regression, using the log of 1985 geography-fitted real openness as a measure of trade openness and the log of 1960 population as a measure of domestic market size. The main advantages and disadvantages of the geography-fitted trade openness measure have already been mentioned: the advantage is that it can be taken as exogenous in the empirical analysis as it is constructed without any reference to productivity growth or productivity levels; the disadvantage is that it captures only part of trade. The method of estimation is least squares with robust standard errors (homoskedasticity can be rejected at the 5-percent level). It can be seen that the extent-of-the-market controls are significant at the 5-percent level in almost all cases. This is the case in column (1) where we control for initial income per capita only; in column (2) where we control for initial income per capita and GADP; in column (3) where we include the two most important growth controls (other than initial GDP per capita) according to Sala-i-Martin (1997a,b); in column (4) where we include the three most robust growth controls (other than initial GDP per capita) according to Doppelhofer, Miller and Sala-i-Martin (2003); in column (5) where we include the five most robust growth controls (other than initial GDP per capita) according to Doppelhofer, Miller and Sala-iMartin (2003); and in column (6) where we include the eleven robust control variables according to Doppelhofer, Miller and Sala-i-Martin (2003). In particular, the interaction 
effect is always significantly negative at the 5-percent level, except in column (2) where it is only significant at the 10-percent level. Hence, geography-fitted real openness had a greater effect on economic growth rates in countries with smaller domestic markets. The Pvalues of the (joint) hypothesis that geography-fitted real openness does not affect economic growth over the 1960-1996 period in the last row of the top panel indicate that this hypothesis can be rejected at the 2-percent level in all cases. Using RLAW instead of GADP (not in the table) as a measure of institutional quality yields very similar results.

\section{Two-Stage Least-Squares Results}

Table 3 contains the results of estimating the growth regression in (1) using the log of average real openness 1960-1996 as a measure of trade openness and the log of 1960 population as a measure of domestic market size. The method of estimation is TSLS (homoskedasticity cannot be rejected at the 10-percent level ${ }^{8}$ ). Column (1) reports the most basic specification, without institutional quality or other controls except the initial level of income per capita. The instruments used to estimate the equation are the log of geographyfitted real openness and the log of geography-fitted real openness interacted with domestic market size as well as the initial level of income per capita. It can be seen that the results indicate very significant effects of trade and domestic market size on 1960-1996 growth rates and also that trade openness mattered more for growth in countries that had smaller 1960 domestic market, confirming the hypothesis of Alesina, Spolaore, and Wacziarg (2000). Column (2) adds the GADP measure of institutional quality to the empirical analysis and the three variables suggested by Hall and Jones (1999) to the instrument list (the fraction of the population speaking English at birth; the fraction of the population speaking one of the five primary European languages at birth; and the distance from the equator). Adding institutional quality results in a somewhat lower effect of trade openness and domestic market size but both effects remain significant at the 5-percent level. Moreover, the negative interaction term, indicating that trade mattered more for countries with smaller domestic markets, is significant at the 7-percent level. The overidentifying restriction is rejected for this specification however (last row of the bottom panel). Column

\footnotetext{
${ }^{8}$ The heteroskedasticity tests that we use are those recommended by Baum, Schaffer, and Stillman (2003) for instrumental-variables regressions.
} 
(3) augments the specification with the two growth controls that Sala-i-Martin (1997a,b) considers most important. The instruments used are those of the second column plus the two variables that have been added. Again, the effect of trade openness and domestic market size falls somewhat but is still significant at the 5- and 7-percent level respectively. The negative interaction effect is significant at the 9-percent level. The overidentifying restriction cannot be rejected at the 10-percent level for this specification. Column (4) uses the three most robust growth controls of Doppelhofer, Miller, and Sala-i-Martin (2003) instead of the two that Sala-i-Martin $(1997 \mathrm{a}, \mathrm{b})$ considers most important. The instruments used are those of the second column plus the three controls. Now all the extent-of-themarket variables are significant at the 5-percent level. But the overidentifying restriction is rejected for this specification. Column (5) uses the five most robust growth controls according to Doppelhofer, Miller, and Sala-i-Martin (2003) (which include the two that Sala-i-Martin (1997a,b) considers most important). The instruments used are those in the third column plus the additional controls. Again, the effects of trade openness and domestic market size fall somewhat (compared to the second column) but both remain significant at the 5-percent level. The negative interaction effect is also significant at the 5percent level. The overidentifying restriction cannot be rejected at the 10-percent level for this specification. Column (6) uses the full set of robust growth controls according to Doppelhofer, Miller, and Sala-i-Martin (2003). The instruments used are those in the third column plus the additional controls. The effect of trade openness and domestic market size as well as the negative interaction effect remain significant at the 5-percent level. And the overidentifying restriction cannot be rejected at the 10-percent level for this specification. The last row in the top panel reports the P-values of the (joint) hypothesis that trade does not matter for 1960-1996 growth for all specifications (the hypothesis that both the effect of trade and the interaction effect are zero). It can be seen that this hypothesis can always be rejected at the 8-percent level. Using RLAW instead of GADP (not in the table) as a measure of institutional quality yields very similar results.

Table 4 checks whether the instruments used in the TSLS analysis in Table 3 are closely related to institutional quality, real openness, and the interaction term between real openness and domestic market size. To investigate this, we regress the three variables on 
the instruments and the controls used in each specification of Table 3. We then performed $F$-tests for the joint significance of the instruments in these regressions, following Alesina, Spolaore, and Wacziarg (2000). For example, the first value in the row entitled "Specification 1" (16.83) is the F-statistic of excluding all trade-instruments from the firststage regression for our measure of trade openness (the log of real openness); the trade instruments are the log of geography-fitted trade and the log of geography-fitted trade interacted with the log of 1960 population. The second value in the row entitled "Specification 1" (17.82) is the F-statistic of excluding all trade-instruments from the firststage regression for the interaction term between trade openness and domestic market size. The F-statistics and p-values compare favorably to those of Alesina, Spolaore, and Wacziarg (2000, 2003) and Spolaore and Wacziarg (2002) for example. High F-statistics in our application do not necessarily imply that weak-instrument problems are absent however. This is because the well-known Staiger and Stock (1997) F-statistic rule of thumb applies to models with one endogenous variable only. Intuitively, in models with two or more endogenous variables, weak-instrument problems may arise because, even if instruments are very significant determinants of each endogenous variable, they may be unable to predict the difference between endogenous variables. It is for this reason that we will consider test-statistics that are asymptotically valid in the presence of weak instruments and use estimators that have been shown to be more robust to weak-instrument problems than two-stage least-squares.

Table 5 estimates selected specifications of the growth regression in (1) using the log of nominal openness as measure of trade openness. The instruments used are identical to those used in the specification with the log of real openness, only that we use the log of geography-fitted nominal openness instead of geography-fitted real openness (that is, we adapt the geography-fitted trade instrument to the trade openness measure used). The extent of the market does not seem to be a robust determinant of 1960-1996 growth rates in this case. For example, domestic market size is only significant at the 5- or 10-percent level in columns (3) and (4) when we control for the three most robust controls according to Doppelhofer, Miller, and Sala-i-Martin (2003). But in this case, the (joint) hypothesis that trade matters for economic growth can be rejected at the 10-percent level (last row of 
top panel). And the overidentifying restriction can be rejected at the 10-percent level (last row of the bottom panel). Moreover, when we control for the eleven robust growth controls according to Doppelhofer, Miller, and Sala-i-Martin (2003), both the linear effect of trade and domestic market size are insignificant at the 10-percent level. The only individually significant extent-of-the-market variable is the negative interaction effect. Using (the level of) nominal openness instead of log nominal openness as a measure of trade openness yields that trade is an even less robust determinant of 1960-1996 growth rates.

Table 6 estimates the growth regression in (1) using the Acemoglu, Johnson, and Robinson (2001) sample of former colonies and their instruments for institutional quality (concentrating on former colonies reduces the sample size to around 66 observations). The analysis concentrates on rule of law as a measure of institutional quality, following Rodrik, Subramanian, and Trebbi (2002) (rule of law is available for more countries than the institutional quality measure used by AJR and RST argue that rule of law is conceptually close to the AJR measure). The method of estimation is TSLS and the measure of trade openness is the log of real openness. Column (1) reports the extent-of-the-market specification without any control variables except the initial level of income per capita and institutional quality. The instruments used to estimate the equation are the log of geography-fitted real openness, the log of geography-fitted real openness interacted with domestic market size, the log of historic settler mortality and the fraction of the population with European origin in 1900 from Acemoglu, Johnson, and Robinson (2001), and the log of the initial level of income per capita. ${ }^{9}$ It can be seen that the results indicate very significant effects of trade and domestic market size on 1960-1996 growth rates and also that trade openness mattered more for growth in countries that had smaller 1960 domestic market. Moreover, the (joint) hypothesis that trade does not matter for economic growth can be rejected at the 2-percent level. Column (2) adds the two growth controls that Sala-iMartin (1997a,b) considers most important. This results in a somewhat lower effect of trade and domestic market size, but both are still significant at the 10-percent level.

9 The institutional quality variable is insignificant at the 10-percent level in all specifications in Table 6 when we do not use the fraction of Europeans in 1900 as an instrument. The same holds for the extent-of-the-market variables. 
Moreover, the (joint) hypothesis that trade does not matter for economic growth can be rejected at the 9-percent level. Column (3) only uses 1960 primary school enrollment as a growth control. 1960 primary school enrollment is the only variable out of the five most robust growth controls according to Doppelhofer, Miller, and Sala-i-Martin (2003) that is significant at the 10-percent level; the other four growth controls are individually and jointly insignificant at the 10-percent level. The effect of trade and domestic market size is now significant at the 5-percent level; the (negative) interaction effect is significant at the 6-percent level. And the (joint) hypothesis that trade matters for economic growth can be rejected at the 5-percent level. Column (4) adds a dummy for countries in Subsaharan Africa to the analysis. This dummy and the 1960 primary school enrollment are the only two variables out of the eleven robust growth controls according to Doppelhofer, Miller, and Sala-i-Martin (2003) that are significant at the 10-percent level; the other nine growth controls are individually and jointly insignificant at the 10-percent level. Now all the extent-of-the-market variables are significant at the 5-percent level. Column (6) eliminates 1960 primary school enrollment, which is insignificant in the previous column, from the analysis. All the extent-of-the-market variables remain significant at the 5-percent level in this case. The last row in the bottom panel shows that the overidentifying restriction cannot be rejected at the 10-percent level.

Table 7 checks whether the instruments are closely related to institutional quality, real openness, and the interaction term between real openness and domestic market size in the Acemoglu, Johnson, and Robinson (2001) former colonies sample. To investigate this, we regress the three variables on the instruments and the controls used in each specification of Table 6 . We then performed $F$-tests for the joint significance of the excluded instruments in these regressions. The picture emerging from the table is that, according to the Fstatistics, the Acemoglu, Johnson, and Robinson (2001) instruments for institutional quality work better in the former colonies sample than the Hall and Jones (1999) instruments in the largest possible sample. But the geography-fitted trade instruments work better in the largest possible sample than in the former colonies sample. 


\section{(Fuller) LIML Results and Kleibergen Significance Tests}

A very recent, rapidly growing econometric literature emphasizes various important statistical problems that may arise when instrumental-variables estimators are based on low-quality instruments. The literature also suggests several ways to ensure that results are not driven by weak instruments. On the one hand, Kleibergen $(2001,2002)$ and Moreira (2003) suggest test-statistics that are asymptotically valid even if instruments are weak. On the other hand, Stock, Wright, and Yogo (2002) and Hahn and Hausman (2003) suggest using Fuller LIML estimators, which they show using Monte-Carlo studies to have better finite-sample properties than TSLS estimators when instruments are weak.

Table 8 therefore presents Fuller LIML estimates of the effect of real openness and domestic market size on 1960-1996 growth. The results are given for two values of the Fuller constant, 4 and 1. The Fuller constant 1 results in the most unbiased estimator and is recommended when one wants to test hypotheses; the Fuller constant 4 minimizes the mean square error of the estimators (Fuller (1977)). It can be seen that Fuller LIML estimates are almost identical to TSLS estimates in Table 3. Using RLAW instead of GADP (not in the table) as a measure of institutional quality yields very similar results.

We also tested the (joint) hypothesis that trade does not matter for 1960-1996 growth (the hypothesis that both the effect of trade and the interaction effect are zero) for all specifications in Table 3 using the Kleibergen and the Moreira test statistics. The Kleibergen tests statistic yields that the hypothesis that trade does not matter can be rejected at the 5-percent level for all specifications except the one in column (2) where the $\mathrm{P}$-value is 0.068 . The Moreira test statistic yields that the hypothesis that trade does not matter can in all cases be rejected at the 5-percent level. The results are almost identical when we use rule of law to measure institutional quality.

Table 9 presents Fuller LIML estimates for the Acemoglu, Johnson, and Robinson (2001) extended former colonies sample. It can be seen that the Fuller LIML results are similar to the TSLS results in Table 6. We also tested the hypothesis that trade does not matter for 1960-1996 growth for all specifications in Table 6 using the Kleibergen and the Moreira test statistics. The Kleibergen tests statistic yields that the hypothesis that trade does not matter can be rejected at the 5-percent level for all specifications except the one in 
column (2) where the P-value is 0.075 . The Moreira test statistic yields that the hypothesis that trade does not matter can in all cases be rejected at the 5-percent level.

\section{Conclusions}

Our empirical results indicate that trade and extent of the market were robust determinants of 1960-1996 economic growth. Moreover, trade mattered more for growth where domestic markets were smaller, confirming the hypothesis of Alesina, Spolaore, and Wacziarg (2000). The interaction effect between trade and domestic market size implies that the marginal effect of trade on 1960-1996 economic growth depends on the size of the country. Focusing on the country with median population in 1960, our results yield that an

increase in real openness from the $25^{\text {th }}$ percentile to the $75^{\text {th }}$ percentile is associated with a 0.8 percent increase in the annual growth rate. 


\section{References}

Acemoglu, Daron, Simon Johnson, and James A. Robinson (2001), “The Colonial Origins of Comparative Development: An Empirical Investigation," American Economic Review, 91(5), pp. 1369-1401.

Ades, Alberto, and Edward L. Glaeser (1999), "Evidence on Growth, Increasing Returns, and the Extent of the Market," Quarterly Journal of Economics, 114(3), pp.1025-45.

Alcalá, Francisco and Antonio Ciccone (2003), "Trade and Productivity," forthcoming Quarterly Journal of Economics.

Alesina, Alberto, Enrico Spolaore, and Romain Wacziarg (2000), "Economic Integration and Political Disintegration," American Economic Review, 90(5), pp. 1276-96.

Alesina, Alberto, Enrico Spolaore, and Romain Wacziarg (2003), "Trade, Growth and the Size of Countries," Harvard Institute of Economic Research Discussion Paper No 1995, Cambridge MA.

Barro, Robert (1991), "Economic Growth in a Cross Section of Countries," Quarterly Journal of Economics, 106(2), pp. 407-443.

Barro, Robert, J. and Xavier Sala-i-Martin (1995), Economic Growth, MIT Press, Cambridge, MA, 1999. (First edition published by McGraw-Hill, New York, 1995).

Baum, Christopher F., Mark E. Schaffer, and Steven Stillman (2003), "Instrumental Variables and GMM: Estimation and Testing," Boston College Working Paper No. 545, Boston MA.

Caselli, Francesco, Gerardo Esquivel and Fernando Lefort (1996), "Reopening the Convergence Debate: A New Look at Cross-Country Growth Empirics," Journal of Economic Growth, 1(3), pp. 363-89.

Dollar, David, and Aart Kraay (2003), "Institutions, Trade, and Growth," Journal of Monetary Economics, 50(1), pp. 133-162.

Doppelhofer, Gernot, Robert Miller and Xavier Sala-i-Martin (2003), "Determinants of Long-Term Growth: A Bayesian Averaging of Classical Estimates (BACE) Approach," forthcoming American Economic Review.

Frankel, Jeffrey, and David Romer (1999), "Does Trade Cause Growth?" American Economic Review, 89(3), pp. 379-99.

Frankel, Jeffrey, and Andrew Rose (2002), "An Estimate of the Effect of Common Currencies on Trade and Income," Quarterly Journal of Economics, 117(2), pp. 437466.

Fuller, Wayne (1997), "Some Properties of a Modification of the Limited Information Estimator," Econometrica, 45(3), pp. 939-954.

Hahn, Jinyong, and Jerry Hausman (2003), "Weak Instruments: Diagnosis and Cures in Empirical Econometrics," American Economic Review, Papers and Proceedings, 93(2), pp.118-125.

Hall, Robert, and Charles Jones (1999), "Why do some countries produce more output per worker than others?" Quarterly Journal of Economics, 114(1), pp. 83-116.

Harrison, Ann (1996), "Openness and Growth: A Time-Series, Cross-Country Analysis for Developing Countries," Journal of Development Economics, 48(2), pp. 419-47. 
Helpman, Elhanan (1981), "International Trade in the Presence of Product Differentiation, Economies of Scale, and Monopolistic Competition: A Chamberlin-Heckscher-Ohlin Approach," Journal of International Economics, 11(3), pp. 305-40.

Heston, Alan, Robert Summers and Bettina Aten (2002), Penn World Table Version 6.1, Center for International Comparisons at the University of Pennsylvania (CICUP).

International Monetary Fund, Direction of Trade Statistics. Various years, Washington D.C.

Kaufmann, Daniel, Aart Kraay, and Pablo Zoido-Lobatón, "Governance Matters IIUpdated Indicators for 2000/01," World Bank Policy Research Department Working Paper No. 2772, Washington D.C., 2002.

Keefer, Philip and Stephen Knack (1997), "Why Don't Poor Countries Catch Up? A Cross-National Test of an Institutional Explanation", Economic Inquiry, 35, pp. 590602.

Kleibergen, Frank (2001), "Testing Subsets of Structural Parameters in the IV Regression Model," Tinbergen Institute Discussion Paper TI 2000-088/4.

Kleibergen, Frank (2002), "Pivotal Statistics for Testing Structural Parameters in Instrumental Variables Regression," Econometrica, 70(5), pp. 1781-1803.

Knack, Stephen and Philip Keefer (1995), "Institutions and Economic Performance: CrossCountry Tests Using Alternative Institutional Measures," Economics and Politics, 7(3), pp. 201-227.

Knack, Stephen (1996), "Institutions and the Convergence Hypothesis: The Cross-National Evidence," Public Choice, 87, pp. 207-228.

Krugman, Paul (1981), "Intraindustry Specialization and the Gains from Trade," Journal of Political Economy, 89(5), pp. 959-73.

Levine, Ross and David Renelt (1992), “A Sensitivity Analysis of Cross-Country Growth regressions," American Economic Review, 82(4), pp. 942-963.

Mankiw, Gregory, David Romer and David Weil (1992), "A Contribution to the Empirics of Economic Growth," Quarterly Journal of Economics, 107(2), pp. 407-37.

Masters, William and Margaret McMillan (2001), "Climate and Scale in Economic Growth," Journal of Economic Growth 6(3): 167-186.

Moreira, Marcelo (2003), "A Conditional Likelihood Ratio Test for Structural Models," Econometrica, 71(4), pp. 1027-1048.

Rodrik, Dani, Arvind Subramanian and Francesco Trebbi (2002): "Institutions Rule: The Primacy of Institutions over Geography and Integration in Economic Development," NBER Working Paper no 9305, Cambridge, MA.

Sala-i-Martin, Xavier (1997a), "I Just Run Two Million Regressions", American Economic Review, Papers and Proceedings, 87(2), pp. 178-183.

Sala-i-Martin, Xavier (1997b), "I Just Run Four Million Regressions”, NBER Working Paper No. 6252, Cambridge, MA. 
Spolaore, Enrico and Romain Wacziarg (2002), "Borders and Growth", mimeo, Brown University and Stanford University.

Staiger, Douglas, and James H. Stock (1997), "Instrumental Variables Regression with Weak Instruments," Econometrica, 65(3), pp. 557-586.

Stock, James H, Jonathan H. Wright, and Motohiro Yogo (2002), "A Survey of Weak Instrument and Weak Identification in Generalized Method of Moments," Journal of Business and Economic Statistics, 20(4), pp. 528-529.

Wacziarg, Romain (2001), "Measuring the Dynamic Gains from Trade," World Bank Economic Review, 15(3), pp. 393-429.

World Bank (2001), World Development Indicators CD-ROM, Washington D.C. 


\section{Appendix}

\section{Variables}

PCGDP GDP per capita, in 1996 PPP US\$. Source: Heston, Summers and Aten (2002).

ROpen Real Openness. Average of real openness over the period 1960-1996. The value for each year is obtained by multiplying the variables COpen and $\mathrm{P}$ in Heston, Summers and Aten (2002).

NOpen Nominal Openness. Average of nominal openness over the period 1960-1996. Corresponds to the variable COpen in Heston, Summers and Aten (2002).

TRgeofit Real openness predicted by geographic factors in 1985. Source: Alcalá and Ciccone (2003).

TRnomgeofit Nominal openness predicted by geographic factors in 1985. Authors' construction following Alcalá and Ciccone (2003) and Frankel and Romer (1999).

GADP Government anti-diversion policies. Source: Hall and Jones (1999).

RLAW Average of rule of law for periods 1997-1998 and 2000-2001. Source: Kaufmann, Kraay, and Zoido-Lobatón (2002).

Pop60 Total population in 1960. Source: Heston, Summers and Aten (2002)

Variables taken from Doppelhofer, Miller and Sala-i-Martin (2003):

LifExp60 Life expectancy in 1960.

Prim60 Primary school enrollment rate in 1960.

Sub-Sahara Dummy for Sub-Saharan African countries.

Latin America Dummy for Latin American countries.

YsOpen Number of years economy has been open between 1950 and 1994 according to the policy criteria of Sachs and Warner (1995).

Priex $\quad$ Fraction of primary exports in total exports in 1970.

Rerd Real exchange rate distortions.

Confucian Fraction of population that follows Confucian religion.

Muslim Fraction of population that follows Muslim religion.

Protestant Fraction of population that follows Protestant religion.

Mining Fraction of GDP in mining.

Instruments:

Abs(Lat) Absolute value of latitude.

EuroL Fraction of population speaking one of the five primary European languages at birth. Source: Hall and Jones (1996).

EngL Fraction of population speaking English at birth. Source: Hall and Jones (1996).

Mort Historic settler mortality in former colonies. Source: Acemoglu, Johnson, and

Euro1900 Fraction of Europeans in former colonies in 1900. Source: Acemoglu, Johnson, and Robinson (2001). 
Table 1. Institutional quality and Doppelhofer, Miller and Sala-i-Martin (2003) controls (LS)
(1)
(2)
(3)
(4)
(5)
(6)

\begin{tabular}{|c|c|c|c|c|c|c|}
\hline LogPCGDP60 & $\begin{array}{l}-1.46 \\
(0.22)\end{array}$ & $\begin{array}{l}-1.65 \\
(0.22)\end{array}$ & $\begin{array}{l}-1.48 \\
(0.22)\end{array}$ & $\begin{array}{l}-1.42 \\
(0.21)\end{array}$ & $\begin{array}{l}-1.74 \\
(0.21)\end{array}$ & $\begin{array}{l}-1.50 \\
(0.20)\end{array}$ \\
\hline GADP & & $\begin{array}{c}2.97 \\
(0.98)\end{array}$ & & & $\begin{array}{c}4.17 \\
(1.09)\end{array}$ & \\
\hline RLAW & & & $\begin{array}{c}0.65 \\
(0.19)\end{array}$ & & & $\begin{array}{c}0.57 \\
(0.19)\end{array}$ \\
\hline Prim60 & $\begin{array}{c}1.44 \\
(0.67)\end{array}$ & $\begin{array}{c}2.01 \\
(0.67)\end{array}$ & $\begin{array}{c}1.97 \\
(0.65)\end{array}$ & $\begin{array}{c}2.29 \\
(0.65)\end{array}$ & $\begin{array}{c}2.44 \\
(0.60)\end{array}$ & $\begin{array}{c}2.49 \\
(0.62)\end{array}$ \\
\hline LifExp60 & $\begin{array}{c}0.10 \\
(0.02)\end{array}$ & $\begin{array}{c}0.07 \\
(0.02)\end{array}$ & $\begin{array}{c}0.06 \\
(0.02)\end{array}$ & $\begin{array}{c}0.06 \\
(0.02)\end{array}$ & $\begin{array}{c}0.04 \\
(0.02)\end{array}$ & $\begin{array}{c}0.03 \\
(0.02)\end{array}$ \\
\hline YsOpen & $\begin{array}{c}1.87 \\
(0.44)\end{array}$ & $\begin{array}{c}1.34 \\
(0.46)\end{array}$ & $\begin{array}{c}1.26 \\
(0.65)\end{array}$ & $\begin{array}{c}1.41 \\
(0.39)\end{array}$ & $\begin{array}{c}0.94 \\
(0.38)\end{array}$ & $\begin{array}{c}1.00 \\
(0.40)\end{array}$ \\
\hline Mining & $\begin{array}{c}4.11 \\
(1.55)\end{array}$ & $\begin{array}{c}3.52 \\
(1.51)\end{array}$ & $\begin{array}{c}3.60 \\
(1.47)\end{array}$ & $\begin{array}{c}5.95 \\
(1.39)\end{array}$ & $\begin{array}{c}5.22 \\
(1.31)\end{array}$ & $\begin{array}{c}5.58 \\
(1.34)\end{array}$ \\
\hline Confucian & $\begin{array}{c}6.10 \\
(1.66)\end{array}$ & $\begin{array}{c}5.53 \\
(1.60)\end{array}$ & $\begin{array}{c}5.33 \\
(1.59)\end{array}$ & $\begin{array}{c}4.71 \\
(1.50)\end{array}$ & $\begin{array}{c}4.39 \\
(1.39)\end{array}$ & $\begin{array}{c}4.09 \\
(1.45)\end{array}$ \\
\hline Latin America & & & & $\begin{array}{l}-0.61 \\
(0.33)\end{array}$ & $\begin{array}{l}-0.06 \\
(0.34)\end{array}$ & $\begin{array}{l}-0.41 \\
(0.32)\end{array}$ \\
\hline Sub-Sahara & & & & $\begin{array}{l}-0.68 \\
(0.40)\end{array}$ & $\begin{array}{l}-0.86 \\
(0.38)\end{array}$ & $\begin{array}{l}-0.86 \\
(0.39)\end{array}$ \\
\hline Muslim & & & & $\begin{array}{c}1.00 \\
(0.44)\end{array}$ & $\begin{array}{c}1.07 \\
(0.41)\end{array}$ & $\begin{array}{c}0.82 \\
(0.43)\end{array}$ \\
\hline Protestant & & & & $\begin{array}{l}-0.64 \\
(0.46)\end{array}$ & $\begin{array}{l}-0.97 \\
(0.43)\end{array}$ & $\begin{array}{l}-0.80 \\
(0.49)\end{array}$ \\
\hline Priex & & & & $\begin{array}{l}-0.98 \\
(0.51)\end{array}$ & $\begin{array}{l}-0.59 \\
(0.48)\end{array}$ & $\begin{array}{l}-0.82 \\
(0.49)\end{array}$ \\
\hline Rerd & & & & $\begin{array}{l}-0.006 \\
(0.003)\end{array}$ & $\begin{array}{c}-0.004 \\
0.002\end{array}$ & $\begin{array}{l}-0.004 \\
(0.002)\end{array}$ \\
\hline Sample Size & 100 & 99 & 99 & 95 & 95 & 95 \\
\hline Rsquared & 0.66 & 0.69 & 0.69 & 0.76 & 0.79 & 0.79 \\
\hline
\end{tabular}

Notes: The left-hand-side variable is $\log ($ PCGDP96/PCGDP60)*100/36, where PCGDP stands for PPP GDP per capita. Least-squares estimation (standard errors in parentheses). All regressions include a constant. GADP (government anti-diversion policies) is the variable for institutional quality used in Hall and Jones (1999). RLAW is the rule of law index of Kaufmann, Kraay, ZoidoLobaton (2002). Columns (1), (2) and (3) include in the specification the five most important control variables (other than initial GDP per capita) according to Doppelhofer, Miller and Sala-iMartin (2003). Columns (4), (5) and (6) include in the specification the full set of variables robustly related to growth according to Doppelhofer, Miller and Sala-i-Martin (2003). 
Table 2. Geography-fitted real openness and GADP (LS)

\begin{tabular}{|c|c|c|c|c|c|c|}
\hline $\begin{array}{l}\text { Extent-of-Market } \\
\text { Controls }\end{array}$ & (1) & (2) & (3) & (4) & (5) & (6) \\
\hline LogTRgeofit & $\begin{array}{l}3.29 * * \\
(1.05)\end{array}$ & $\begin{array}{c}2.32 * * \\
(1.03)\end{array}$ & $\begin{array}{l}\mathbf{1 . 8 5} * * \\
(0.70)\end{array}$ & $\begin{array}{c}2.23 * * \\
(0.86)\end{array}$ & $\begin{array}{c}\mathbf{2 . 1 5} * * \\
(0.51)\end{array}$ & $\begin{array}{c}\mathbf{1 . 6 0} * * \\
(0.58)\end{array}$ \\
\hline LogTRgeofit*LogPop60 & $\begin{array}{c}-\mathbf{0 . 2 4 * *} \\
(0.10)\end{array}$ & $\begin{array}{l}\mathbf{- 0 . 1 7 *} \\
(0.10)\end{array}$ & $\begin{array}{c}\mathbf{- 0 . 1 4} * * \\
(0.07)\end{array}$ & $\begin{array}{c}\mathbf{- 0 . 1 9} * * \\
(0.09)\end{array}$ & $\begin{array}{c}\mathbf{- 0 . 1 9} * * \\
(0.05)\end{array}$ & $\begin{array}{c}\mathbf{- 0 . 1 7} * * \\
(0.06)\end{array}$ \\
\hline LogPop60 & $\begin{array}{c}\mathbf{0 . 7 4} * * \\
(0.24)\end{array}$ & $\begin{array}{c}\mathbf{0 . 5 1} * * \\
(0.22)\end{array}$ & $\begin{array}{c}\mathbf{0 . 4 2} * * \\
(0.18)\end{array}$ & $\begin{array}{c}\mathbf{0 . 5 2} * * \\
(0.20)\end{array}$ & $\begin{array}{c}\mathbf{0 . 5 1} * * \\
(0.13)\end{array}$ & $\begin{array}{c}0.17 \\
(0.13)\end{array}$ \\
\hline $\begin{array}{l}\text { P-value Hypothesis } \\
\text { Trade Insignificant }\end{array}$ & 0.0001 & 0.008 & 0.012 & 0.019 & 0.00008 & 0.011 \\
\hline Other Controls & & & & & & \\
\hline LogPCGDP60 & $\begin{array}{c}0.21 \\
(0.15)\end{array}$ & $\begin{array}{l}-0.70 \\
(0.26)\end{array}$ & $\begin{array}{l}-1.64 \\
(0.28)\end{array}$ & $\begin{array}{l}-0.67 \\
(0.21)\end{array}$ & $\begin{array}{l}-1.55 \\
(0.22)\end{array}$ & $\begin{array}{l}-1.65 \\
(0.25)\end{array}$ \\
\hline GADP & & $\begin{array}{c}5.76 \\
(1.24)\end{array}$ & $\begin{array}{c}4.11 \\
(1.28)\end{array}$ & $\begin{array}{l}3.27 \\
(1.05)\end{array}$ & $\begin{array}{c}2.38 \\
(1.08)\end{array}$ & $\begin{array}{c}3.98 \\
(1.40)\end{array}$ \\
\hline Prim60 & & & $\begin{array}{l}2.88 \\
(0.74)\end{array}$ & & $\begin{array}{l}1.99 \\
(0.69)\end{array}$ & $\begin{array}{c}2.43 \\
(0.67)\end{array}$ \\
\hline LifExp60 & & & $\begin{array}{c}0.05 \\
(0.02)\end{array}$ & & $\begin{array}{c}0.07 \\
(0.02)\end{array}$ & $\begin{array}{c}0.03 \\
(0.02)\end{array}$ \\
\hline YsOpen & & & & $\begin{array}{l}2.10 \\
(0.43)\end{array}$ & $\begin{array}{c}1.13 \\
(0.36)\end{array}$ & $\begin{array}{c}0.68 \\
(0.33)\end{array}$ \\
\hline Mining & & & & $\begin{array}{c}3.34 \\
(2.41)\end{array}$ & $\begin{array}{c}4.70 \\
(1.88)\end{array}$ & $\begin{array}{c}5.28 \\
(1.23)\end{array}$ \\
\hline Confucian & & & & $\begin{array}{c}5.91 \\
(0.93)\end{array}$ & $\begin{array}{l}5.19 \\
(0.87)\end{array}$ & $\begin{array}{c}4.23 \\
(0.76)\end{array}$ \\
\hline Latin America & & & & & & $\begin{array}{l}-0.34 \\
(0.37)\end{array}$ \\
\hline Sub-Sahara & & & & & & $\begin{array}{l}-1.17 \\
(0.37)\end{array}$ \\
\hline Muslim & & & & & & $\begin{array}{c}0.94 \\
(0.36)\end{array}$ \\
\hline Protestant & & & & & & $\begin{array}{l}-1.23 \\
(0.35)\end{array}$ \\
\hline Priex & & & & & & $\begin{array}{l}-1.00 \\
(0.49)\end{array}$ \\
\hline RERD & & & & & & $\begin{array}{l}-0.004 \\
(0.002)\end{array}$ \\
\hline Sample Size & 98 & 98 & 98 & 98 & 98 & 94 \\
\hline Rsquared & 0.25 & 0.42 & 0.64 & 0.56 & 0.72 & 0.83 \\
\hline
\end{tabular}


Notes: The left-hand-side variable is $\log$ (PCGDP96/PCGDP60)*100/36, where PCGDP stands for PPP GDP per capita. Least-squares estimation (standard errors in parentheses). All regressions include a constant. LogTRgeofit is the log of 1985 geography-fitted real openness from Alcalá and Ciccone (2003) and is used as the measure of trade openness. GADP (government anti-diversion policies) is the variable for institutional quality used in Hall and Jones (1999). In column (3) we include the two most important growth controls (other than initial GDP per capita) according to Sala-i-Martin (1997a,b). In column (4) we include the three most robust growth control (other than GDP per capita) according to Doppelhofer, Miller and Sala-i-Martin (2003). In column (5) we include the five most robust growth controls (other than initial GDP per capita) according to Doppelhofer, Miller and Sala-i-Martin (2003). And in column (6) we include the full set of variables robustly related to growth according to Doppelhofer, Miller and Sala-i-Martin (2003). ** significant 5\% level; * 10\% level (significant "other controls" are not marked). 
Table 3. Real openness and GADP (TSLS)

\begin{tabular}{|c|c|c|c|c|c|c|}
\hline $\begin{array}{l}\text { Extent-of-Market } \\
\text { Controls }\end{array}$ & (1) & (2) & (3) & (4) & (5) & (6) \\
\hline LogROpen & $\begin{array}{c}\mathbf{5 . 6 9} * * \\
(1.55)\end{array}$ & $\begin{array}{l}3.72 * * \\
(1.65)\end{array}$ & $\begin{array}{l}2.99 * * \\
(1.45)\end{array}$ & $\begin{array}{c}\text { 3.01** } \\
(1.29)\end{array}$ & $\begin{array}{c}\mathbf{2 . 7 8} * * \\
(1.14)\end{array}$ & $\begin{array}{l}2.33 * * \\
(1.22)\end{array}$ \\
\hline LogROpen* LogPop60 & $\begin{array}{c}-\mathbf{0 . 3 9} * * \\
(0.17)\end{array}$ & $\begin{array}{l}\mathbf{- 0 . 2 9 *} \\
(0.16)\end{array}$ & $\begin{array}{l}-\mathbf{0 . 2 4} * \\
(0.14)\end{array}$ & $\begin{array}{c}-\mathbf{0 . 2 8} * * \\
(0.13)\end{array}$ & $\begin{array}{c}-\mathbf{0 . 2 6} * * \\
(0.12)\end{array}$ & $\begin{array}{c}-\mathbf{0 . 2 8} * * \\
(0.11)\end{array}$ \\
\hline LogPop60 & $\begin{array}{c}\mathbf{3 . 6 8}^{* * *} \\
(1.34)\end{array}$ & $\begin{array}{l}\mathbf{2 . 6 0} * * \\
(1.34)\end{array}$ & $\begin{array}{l}\mathbf{2 . 1 5} * \\
(1.18)\end{array}$ & $\begin{array}{c}2.41 * * \\
(1.06)\end{array}$ & $\begin{array}{c}2.24 * * \\
(0.96)\end{array}$ & $\begin{array}{l}\mathbf{2 . 0 6} * * \\
(0.94)\end{array}$ \\
\hline $\begin{array}{l}\mathrm{P} \text {-value Hypothesis } \\
\text { Trade Insignificant }\end{array}$ & 0.000 & 0.044 & 0.079 & 0.067 & 0.052 & 0.046 \\
\hline Other Controls & & & & & & \\
\hline LogPCGDP60 & $\begin{array}{l}-0.39 \\
(0.27)\end{array}$ & $\begin{array}{l}-0.77 \\
(0.41)\end{array}$ & $\begin{array}{l}-1.62 \\
(0.33)\end{array}$ & $\begin{array}{l}-0.78 \\
(0.31)\end{array}$ & $\begin{array}{l}-1.55 \\
(0.29)\end{array}$ & $\begin{array}{l}-1.44 \\
(0.34)\end{array}$ \\
\hline GADP & & $\begin{array}{c}4.54 \\
(2.75)\end{array}$ & $\begin{array}{c}3.88 \\
(2.82)\end{array}$ & $\begin{array}{l}3.34 \\
(2.40)\end{array}$ & $\begin{array}{l}3.44 \\
(2.46)\end{array}$ & $\begin{array}{c}2.39 \\
(3.99)\end{array}$ \\
\hline Prim60 & & & $\begin{array}{c}2.39 \\
(0.84)\end{array}$ & & $\begin{array}{c}1.86 \\
(0.79)\end{array}$ & $\begin{array}{c}2.26 \\
(0.67)\end{array}$ \\
\hline LifExp60 & & & $\begin{array}{c}0.04 \\
(0.03)\end{array}$ & & $\begin{array}{c}0.04 \\
(0.03)\end{array}$ & $\begin{array}{c}0.048 \\
(0.043)\end{array}$ \\
\hline YsOpen & & & & $\begin{array}{c}2.07 \\
(0.69)\end{array}$ & $\begin{array}{l}1.13 \\
(0.63)\end{array}$ & $\begin{array}{c}1.21 \\
(0.70)\end{array}$ \\
\hline Mining & & & & $\begin{array}{c}1.48 \\
(1.79)\end{array}$ & $\begin{array}{l}2.48 \\
(1.79)\end{array}$ & $\begin{array}{c}5.21 \\
(2.02)\end{array}$ \\
\hline Confucian & & & & $\begin{array}{l}5.51 \\
(1.96)\end{array}$ & $\begin{array}{l}4.75 \\
(1.75)\end{array}$ & $\begin{array}{c}4.42 \\
(1.62)\end{array}$ \\
\hline Latin America & & & & & & $\begin{array}{l}-0.43 \\
(0.69)\end{array}$ \\
\hline Sub-Sahara & & & & & & $\begin{array}{l}-0.87 \\
(0.44)\end{array}$ \\
\hline Muslim & & & & & & $\begin{array}{c}1.02 \\
(0.46)\end{array}$ \\
\hline Protestant & & & & & & $\begin{array}{l}-1.55 \\
(0.60)\end{array}$ \\
\hline Priex & & & & & & $\begin{array}{l}-1.01 \\
(0.68)\end{array}$ \\
\hline Rerd & & & & & & $\begin{array}{l}-0.003 \\
(0.003)\end{array}$ \\
\hline $\begin{array}{l}\text { Sample Size } \\
\text { P-value Overidentifying }\end{array}$ & 98 & 98 & 98 & 98 & 98 & 95 \\
\hline Restrictions & -- & 0.02 & 0.22 & 0.04 & 0.19 & 0.72 \\
\hline
\end{tabular}


Notes: The left-hand-side variable is $\log$ (PCGDP96/PCGDP60)*100/36, where PCGDP stands for PPP GDP per capita. Two-stage least-squares (TSLS) estimation. All regressions include a constant. LogROpen is the log of average real openness 1960-1996. GADP (government antidiversion policies) is the variable for institutional quality used in Hall and Jones (1999). In column (3) we include the two most important growth controls (other than initial GDP per capita) according to Sala-i-Martin (1997a,b). In column (4) we include the three most robust growth control (other than initial GDP per capita) according to Doppelhofer, Miller and Sala-i-Martin (2003). In column (5) we include the five most robust growth controls (other than GDP per capita) according to Doppelhofer, Miller and Sala-i-Martin (2003). And in column (6) we include the full set of variables robustly related to growth according to Doppelhofer, Miller and Sala-i-Martin (2003). Instruments always used are the log of TRgeofit and the product of this variable with the $\log$ of population in 1960. When GADP is included in the specification, we use the fraction of people speaking English at birth (EngL), the fraction of people speaking one of the five primary European languages at birth (EuroL), and distance from the equator (AbsLati) as additional instruments. The included controls are also used as instruments. ** significant 5\% level; *10\% level (significant "other controls" are not marked). 
Table 4. First-Stage $F$-tests for the Instruments

\begin{tabular}{|c|c|c|c|}
\hline & (1) & (2) & (3) \\
\hline Endogenous variable & LogROpen & $\begin{array}{c}\text { LogROpen* } \\
\text { LogPop60 }\end{array}$ & GADP \\
\hline $\begin{array}{l}\text { Specification } 1 \text { in Table } 3 \\
\text { F-statistic } \\
\text { (p-value) }\end{array}$ & $\begin{array}{c}16.83 \\
(0.000)\end{array}$ & $\begin{array}{c}17.82 \\
(0.000)\end{array}$ & - \\
\hline $\begin{array}{l}\text { Specification } 2 \text { in Table } 3 \\
\text { F-statistic } \\
\text { (p-value) }\end{array}$ & $\begin{array}{c}14.09 \\
(0.000)\end{array}$ & $\begin{array}{l}16.68 \\
(0.000)\end{array}$ & $\begin{array}{c}7.22 \\
(0.000)\end{array}$ \\
\hline $\begin{array}{l}\text { Specification } 3 \text { in Table } 3 \\
\text { F-statistic } \\
\text { (p-value) }\end{array}$ & $\begin{array}{c}8.89 \\
(0.000)\end{array}$ & $\begin{array}{c}12.77 \\
(0.000)\end{array}$ & $\begin{array}{c}5.98 \\
(0.001)\end{array}$ \\
\hline $\begin{array}{l}\text { Specification } 4 \text { in Table } 3 \\
\text { F-statistic } \\
\text { (p-value) }\end{array}$ & $\begin{array}{c}11.17 \\
(0.000)\end{array}$ & $\begin{array}{c}14.39 \\
(0.000)\end{array}$ & $\begin{array}{c}9.68 \\
(0.001)\end{array}$ \\
\hline $\begin{array}{l}\text { Specification } 5 \text { in Table } 3 \\
\text { F-statistic } \\
\text { (p-value) }\end{array}$ & $\begin{array}{c}9.24 \\
(0.000)\end{array}$ & $\begin{array}{c}12.39 \\
(0.000)\end{array}$ & $\begin{array}{c}6.96 \\
(0.000)\end{array}$ \\
\hline $\begin{array}{l}\text { Specification } 6 \text { in Table } 3 \\
\text { F-statistic } \\
\text { (p-value) }\end{array}$ & $\begin{array}{c}8.55 \\
(0.000)\end{array}$ & $\begin{array}{c}15.17 \\
(0.000)\end{array}$ & $\begin{array}{c}4.2 \\
(0.01)\end{array}$ \\
\hline
\end{tabular}

Notes: F-tests and p-values of the exclusion restriction of the excluded instruments for each endogenous variable in the first-stage regressions. See the second row for the left-hand-side variable of these regressions. 
Table 5. Log Nominal openness (TSLS)

(1)

(2)

(3)

(4)

(5)

(6)

Extent-of-Market Controls

$\begin{array}{lllllll}\text { LogNOpen } & \mathbf{2 . 9 6 *} & 2.75 & \mathbf{3 . 4 0}^{* *} & \mathbf{3 . 1 9} * & 2.03 & 1.87 \\ & (1.64) & (1.68) & (1.69) & (1.66) & (1.48) & (1.53) \\ \text { LogNOpen* LogPop60 } & -0.22 & -0.20 & \mathbf{- 0 . 3 0 *} & \mathbf{- 0 . 2 9 *} & \mathbf{- 0 . 2 8 * *} & \mathbf{- 0 . 2 8}^{* *} \\ & (0.16) & (0.16) & (0.16) & (0.16) & (0.13) & (0.13) \\ \text { LogPop60 } & 1.15 & 1.01 & \mathbf{1 . 4 1}^{* *} & \mathbf{1 . 3 6} & 0.84 & 0.79 \\ & (0.70) & (0.70) & (0.70) & (0.69) & (0.59) & (0.62)\end{array}$

P-value Hypothesis

Trade Insignificant

$0.097 \quad 0.140$

0.132

$0.160 \quad 0.073$

0.043

Other Controls

\begin{tabular}{|c|c|c|c|c|c|c|}
\hline LogPCGDP60 & $\begin{array}{l}-1.76 \\
(0.30)\end{array}$ & $\begin{array}{l}-1.50 \\
(0.25)\end{array}$ & $\begin{array}{l}-0.83 \\
(0.32)\end{array}$ & $\begin{array}{l}-0.80 \\
(0.27)\end{array}$ & $\begin{array}{l}-1.51 \\
(0.35)\end{array}$ & $\begin{array}{l}-1.33 \\
(0.24)\end{array}$ \\
\hline GADP & $\begin{array}{c}5.66 \\
(2.44)\end{array}$ & & $\begin{array}{c}4.91 \\
(2.26)\end{array}$ & & $\begin{array}{c}1.54 \\
(4.73)\end{array}$ & \\
\hline RLAW & & $\begin{array}{c}1.29 \\
(0.54)\end{array}$ & & $\begin{array}{c}1.17 \\
(0.44)\end{array}$ & & $\begin{array}{l}-0.13 \\
(0.78)\end{array}$ \\
\hline Control Variables Used & $\begin{array}{l}\text { Prim60, } \\
\text { LifExp60 }\end{array}$ & $\begin{array}{l}\text { Prim60, } \\
\text { LifExp60 }\end{array}$ & $\begin{array}{l}\text { Confuc, } \\
\text { YsOpen, } \\
\text { Mining }\end{array}$ & $\begin{array}{l}\text { Confuc, } \\
\text { YsOpen, } \\
\text { Mining }\end{array}$ & $\begin{array}{c}\text { Prim60, } \\
\text { LifExp60, } \\
\text { Confuc, } \\
\text { YsOpen, } \\
\text { Mining, } \\
\text { Muslim, } \\
\text { Prot, Priex, } \\
\text { Latin, Subs, } \\
\text { Rerd }\end{array}$ & $\begin{array}{l}\text { Prim60, } \\
\text { LifExp60, } \\
\text { Confuc, } \\
\text { YsOpen, } \\
\text { Mining, } \\
\text { Muslim, } \\
\text { Prot, Priex, } \\
\text { Latin, Subs, } \\
\text { Rerd }\end{array}$ \\
\hline Sample Size & 98 & 98 & 98 & 98 & 95 & 95 \\
\hline $\begin{array}{l}\text { P-value Overidentifying } \\
\text { Restrictions }\end{array}$ & 0.18 & 0.21 & 0.04 & 0.09 & 0.59 & 0.57 \\
\hline
\end{tabular}

Notes: The left-hand-side variable is $\log$ (PCGDP96/PCGDP60)*100/36, where PCGDP stands for PPP GDP per capita. Two-stage least-squares (TSLS) estimation. All regressions include a constant. LogNOpen is the log of average nominal openness 1960-1996. GADP (government anti-diversion policies) is the variable for institutional quality used in Hall and Jones (1999). RLAW is the rule of law index of Kaufmann, Kraay, ZoidoLobaton (2002). In columns (1) and (2) we include the two most important growth controls (other than initial GDP per capita) according to Sala-i-Martin (1997a,b). In column (3) and (4) we include the three most robust growth control (other than initial GDP per capita) according to Doppelhofer, Miller and Sala-i-Martin (2003). And in column (5) and (6) we include the full set of variables robustly related to growth according to Doppelhofer, Miller and Sala-i-Martin (2003). Instruments always used are the log of geography-fitted nominal openness (instead of geography-fitted real openness), the product of this variable with the log of population in 1960, the fraction of people speaking English at birth (EngL), the fraction of people speaking one of the five primary European languages at birth (EuroL), and distance from the equator (AbsLati). The included controls are also used as instruments. ** significant 5\% level; * $10 \%$ level (significant "other controls" are not marked). 
Table 6. Real openness in former colonies (TSLS)

(1)

Extent-of-Market Controls

\begin{tabular}{|c|c|c|c|c|c|}
\hline LogROpen & $\begin{array}{l}\mathbf{6 . 5 7 * *} \\
(2.33)\end{array}$ & $\begin{array}{l}\mathbf{5 . 1 2} * \\
(2.65)\end{array}$ & $\begin{array}{l}\mathbf{5 . 3 0 * *} \\
(2.23)\end{array}$ & $\begin{array}{l}\mathbf{5 . 5 1 * *} \\
(2.03)\end{array}$ & $\begin{array}{l}\mathbf{6 . 3 2} * * \\
(2.01)\end{array}$ \\
\hline LogROpen*LogPop60 & $\begin{array}{l}\mathbf{- 0 . 5 8} * * \\
(0.25)\end{array}$ & $\begin{array}{l}\mathbf{- 0 . 4 5 *} \\
(0.29)\end{array}$ & $\begin{array}{l}\mathbf{- 0 . 4 7 * *} \\
(0.24)\end{array}$ & $\begin{array}{l}\mathbf{- 0 . 5 1} * * \\
(0.21)\end{array}$ & $\begin{array}{l}-\mathbf{0 . 5 8} * * \\
(0.21)\end{array}$ \\
\hline LogPop60 & $\begin{array}{l}\text { 4.81** } \\
(1.95)\end{array}$ & $\begin{array}{l}3.75^{*} \\
(2.24)\end{array}$ & $\begin{array}{l}3.90 * * \\
(1.85)\end{array}$ & $\begin{array}{l}4.11 * * \\
(1.66)\end{array}$ & $\begin{array}{l}4.66 * * \\
(1.67)\end{array}$ \\
\hline $\begin{array}{l}\text { P-value Hypothesis } \\
\text { Trade Insignificant }\end{array}$ & 0.013 & 0.085 & 0.042 & 0.021 & 0.006 \\
\hline
\end{tabular}

Other Controls

\begin{tabular}{lccccc} 
LogPCGDP60 & -0.56 & -0.98 & -0.98 & -1.03 & -0.74 \\
& $(0.37)$ & $(0.40)$ & $(0.39)$ & $(0.36)$ & $(0.33)$ \\
RLAW & 1.16 & 1.15 & 1.07 & 0.90 & 0.85 \\
& $(0.59)$ & $(0.76)$ & $(0.47)$ & $(0.43)$ & $(0.50)$ \\
Prim60 & & 2.08 & 1.87 & 1.21 & \\
& & $(1.50)$ & $(0.95)$ & $(0.95)$ & \\
LifExp60 & -0.009 & & & \\
& & $(0.05)$ & & & \\
Sub-Sahara & & & & -1.08 & -1.22 \\
& & & & $(0.44)$ & $(0.40)$ \\
Sample Size & 67 & 65 & 65 & 65 & 67 \\
P-value Overidentifying & 0.11 & 0.18 & 0.17 & 0.34 & \\
Restrictions & & & & & 0.31 \\
\hline
\end{tabular}

Notes: The left-hand-side variable is $\log$ (PCGDP96/PCGDP60)*100/36, where PCGDP stands for PPP GDP per capita. Two-stage least-squares (TSLS) estimation. All regressions include a constant. LogROpen is the log of average real openness 1960-1996. RLAW is the rule of law index of Kaufmann, Kraay, Zoido-Lobaton (2002). Instruments always used are the log of TRgeofit, and the product of this variable with the log of population in 1960, as well as the log of historic settler mortality (LogMort) and the fraction of Europeans in 1900 (Euro1900) from AJR (2001). The included controls are also used as instruments. ** significant $5 \%$ level; * 10\% level (significant "other controls" are not marked). 
Table 7. First-Stage $F$-tests for the Instruments

\begin{tabular}{|c|c|c|c|}
\hline & (1) & (2) & (3) \\
\hline Endogenous variable & LogROpen & $\begin{array}{c}\text { LogROpen* } \\
\text { LogPop60 }\end{array}$ & RLAW \\
\hline $\begin{array}{l}\text { Specification } 1 \text { in Table } 6 \\
\text { F-statistic } \\
\text { (p-value) }\end{array}$ & $\begin{array}{c}10.63 \\
(0.000)\end{array}$ & $\begin{array}{c}6.02 \\
(0.004)\end{array}$ & $\begin{array}{c}10.63 \\
(0.000)\end{array}$ \\
\hline $\begin{array}{l}\text { Specification } 2 \text { in Table } 6 \\
\text { F-statistic } \\
\text { (p-value) }\end{array}$ & $\begin{array}{c}6.14 \\
(0.004)\end{array}$ & $\begin{array}{c}5.31 \\
(0.01)\end{array}$ & $\begin{array}{c}6.04 \\
(0.004)\end{array}$ \\
\hline $\begin{array}{l}\text { Specification } 3 \text { in Table } 6 \\
\text { F-statistic } \\
\text { (p-value) }\end{array}$ & $\begin{array}{c}9.57 \\
(0.000)\end{array}$ & $\begin{array}{c}5.42 \\
(0.01)\end{array}$ & $\begin{array}{c}9.57 \\
(0.000)\end{array}$ \\
\hline $\begin{array}{l}\text { Specification } 4 \text { in Table } 6 \\
\text { F-statistic } \\
\text { (p-value) }\end{array}$ & $\begin{array}{c}9.72 \\
(0.000)\end{array}$ & $\begin{array}{c}7.02 \\
(0.002)\end{array}$ & $\begin{array}{c}9.72 \\
(0.000)\end{array}$ \\
\hline $\begin{array}{l}\text { Specification } 5 \text { in Table } 6 \\
\text { F-statistic } \\
\text { (p-value) }\end{array}$ & $\begin{array}{c}10.74 \\
(0.000)\end{array}$ & $\begin{array}{c}6.91 \\
(0.002)\end{array}$ & $\begin{array}{c}10.74 \\
(0.000)\end{array}$ \\
\hline
\end{tabular}

Notes: F-tests and p-values of the exclusion restriction of the excluded instruments for each endogenous variable in the first-stage regressions. See the second row for the left-hand-side variable of these regressions. 
Table 8. Real openness and GADP (Fuller LIML)

\begin{tabular}{|c|c|c|c|c|c|c|c|c|c|c|c|c|}
\hline \multirow[b]{2}{*}{ Extent-of-Market Controls } & \multicolumn{2}{|c|}{$\begin{array}{l}(1) \\
\text { Fuller Constant }\end{array}$} & \multicolumn{2}{|c|}{$\begin{array}{l}(2) \\
\text { Fuller Constant }\end{array}$} & \multicolumn{2}{|c|}{$\begin{array}{l}(3) \\
\text { Fuller Constant }\end{array}$} & \multicolumn{2}{|c|}{$\begin{array}{l}(4) \\
\text { Fuller Constant }\end{array}$} & \multicolumn{2}{|c|}{$\begin{array}{l}(5) \\
\text { Fuller Constant }\end{array}$} & \multicolumn{2}{|c|}{$\begin{array}{l}\text { (6) } \\
\text { Fuller Constant }\end{array}$} \\
\hline & 4 & 1 & 4 & 1 & 4 & 1 & 4 & 1 & 4 & 1 & 4 & 1 \\
\hline LogROpen & $\begin{array}{l}\mathbf{5 . 5 7 * *} \\
(1.49)\end{array}$ & $\begin{array}{l}\mathbf{5 . 6 6} * * \\
(1.53)\end{array}$ & $\begin{array}{l}\mathbf{3 . 8 1} * * \\
(1.78)\end{array}$ & $\begin{array}{l}\mathbf{3 . 9 2}^{* *} \\
(1.91)\end{array}$ & $\begin{array}{l}\mathbf{2 . 9 7} * * \\
(1.42)\end{array}$ & $\begin{array}{l}\mathbf{3 . 0 5}^{* * *} \\
(1.52)\end{array}$ & $\begin{array}{l}\mathbf{2 . 9 8} * * \\
(1.33)\end{array}$ & $\begin{array}{l}\mathbf{2 . 9 5} * * \\
(1.39)\end{array}$ & $\begin{array}{l}\mathbf{2 . 7 8} * * \\
(1.13)\end{array}$ & $\begin{array}{l}\mathbf{2 . 7 9} * * \\
(1.19)\end{array}$ & $\begin{array}{l}\mathbf{2 . 1 5} * \\
(1.17)\end{array}$ & $\begin{array}{l}\mathbf{2 . 1 5} * \\
(1.27)\end{array}$ \\
\hline LogROpen*Log(Pop60) & $\begin{array}{l}-\mathbf{0 . 3 9 * *} \\
(0.16)\end{array}$ & $\begin{array}{l}-\mathbf{- 0 . 3 9} * * \\
(0.16)\end{array}$ & $\begin{array}{l}-\mathbf{- 0 . 2 9 *} \\
(0.17)\end{array}$ & $\begin{array}{l}-0.29 \\
(0.18)\end{array}$ & $\begin{array}{l}-\mathbf{- 0 . 2 4 *} \\
(0.14)\end{array}$ & $\begin{array}{l}-0.24 \\
(0.15)\end{array}$ & $\begin{array}{l}-\mathbf{- 0 . 2 8} * * \\
(0.13)\end{array}$ & $\begin{array}{l}-\mathbf{- 0 . 2 7} * * \\
(0.13)\end{array}$ & $\begin{array}{l}-\mathbf{- 0 . 2 6}^{* * *} \\
(0.11)\end{array}$ & $\begin{array}{l}-\mathbf{- 0 . 2 5 * *} \\
(0.12)\end{array}$ & $\begin{array}{l}-\mathbf{0 . 2 6} * * \\
(0.11)\end{array}$ & $\begin{array}{l}-\mathbf{0 . 2 8} * * \\
(0.11)\end{array}$ \\
\hline LogPop60 & $\begin{array}{l}3.67 * * \\
(1.29)\end{array}$ & $\begin{array}{l}\mathbf{3 . 6 8}^{* *} \\
(1.32)\end{array}$ & $\begin{array}{l}\mathbf{2 . 6 2} * \\
(1.42)\end{array}$ & $\begin{array}{l}\mathbf{2 . 6 6 *} \\
(1.51)\end{array}$ & $\begin{array}{l}\mathbf{2 . 1 4} * \\
(1.16)\end{array}$ & $\begin{array}{l}\mathbf{2 . 1 7} * \\
(1.23)\end{array}$ & $\begin{array}{l}\mathbf{2 . 3 8} * * \\
(1.09)\end{array}$ & $\begin{array}{l}\mathbf{2 . 3 3} * * \\
(1.13)\end{array}$ & $\begin{array}{l}\mathbf{2 . 2 5} * * \\
(0.95)\end{array}$ & $\begin{array}{l}\mathbf{2 . 2 1} * * \\
(1.00)\end{array}$ & $\begin{array}{l}\text { 1.93*** } \\
(0.91)\end{array}$ & $\begin{array}{l}\mathbf{2 . 0 1} * * \\
(0.97)\end{array}$ \\
\hline \multicolumn{12}{|l|}{ P-value Hypothesis } & 0.05 \\
\hline \multicolumn{13}{|l|}{ Other Controls } \\
\hline LogPCGDP60 & $\begin{array}{l}-0.34 \\
(0.26)\end{array}$ & $\begin{array}{c}0.37 \\
(0.27)\end{array}$ & $\begin{array}{l}-0.77 \\
(0.45)\end{array}$ & $\begin{array}{l}-0.76 \\
(0.49)\end{array}$ & $\begin{array}{l}-1.62 \\
(0.33)\end{array}$ & $\begin{array}{l}-1.62 \\
(0.35)\end{array}$ & $\begin{array}{c}0.79 \\
(0.33)\end{array}$ & $\begin{array}{l}-0.81 \\
(0.35)\end{array}$ & $\begin{array}{l}-1.54 \\
(0.29)\end{array}$ & $\begin{array}{l}-1.56 \\
(0.30)\end{array}$ & $\begin{array}{l}-1.37 \\
(0.33)\end{array}$ & $\begin{array}{l}-1.28 \\
(0.40)\end{array}$ \\
\hline GADP & & & $\begin{array}{c}4.34 \\
(3.09)\end{array}$ & $\begin{array}{c}4.11 \\
(3.44)\end{array}$ & $\begin{array}{c}3.89 \\
(2.72)\end{array}$ & $\begin{array}{c}3.86 \\
(3.06)\end{array}$ & $\begin{array}{c}3.42 \\
(2.54)\end{array}$ & $\begin{array}{c}3.56 \\
(2.75)\end{array}$ & $\begin{array}{c}3.38 \\
(2.40)\end{array}$ & $\begin{array}{c}3.66 \\
(2.67)\end{array}$ & $\begin{array}{c}1.95 \\
(3.40)\end{array}$ & $\begin{array}{c}0.73 \\
(4.54)\end{array}$ \\
\hline Control Variables Used & & & & & Prim60, & LifExp60 & $\begin{array}{r}\text { Confuc } \\
\mathrm{M}\end{array}$ & $\begin{array}{l}\text { YsOpen, } \\
\text { ling }\end{array}$ & $\begin{array}{r}\text { Prim60 } \\
\text { Confuc } \\
\mathrm{N}\end{array}$ & $\begin{array}{l}\text { ifExp60, } \\
\text { YsOpen, } \\
\text { aing }\end{array}$ & $\begin{array}{r}\text { Prim60 } \\
\text { Confuc } \\
\text { Mining } \\
\text { Prot, } P \\
\text { Sub }\end{array}$ & $\begin{array}{l}\text { ifExp60, } \\
\text { YsOpen, } \\
\text { Muslim, } \\
\text { ex, Latin, } \\
\text { Rerd }\end{array}$ \\
\hline Sample Size & & 8 & & 8 & & 8 & & 8 & & 8 & & 4 \\
\hline
\end{tabular}

Jotes: The left-hand-side variable is $\log$ (PCGDP96/PCGDP60)*100/36, where PCGDP stands for PPP GDP per capita. Fuller LIML estimates using two values of th iuller constant: 4 and 1. All regressions include a constant. The specifications follow Table 3. ** significant 5\% level; * 10\% level (significant "other controls" are no larked). 
Table 9. Real openness in former colonies (Fuller LIML)

\begin{tabular}{|c|c|c|c|c|c|c|c|c|c|c|}
\hline \multirow[b]{2}{*}{ Extent-of-Market Controls } & \multicolumn{2}{|c|}{$\begin{array}{c}\text { (1) } \\
\text { Fuller Constant }\end{array}$} & \multicolumn{2}{|c|}{$\begin{array}{l}\text { (2) } \\
\text { Fuller Constant }\end{array}$} & \multicolumn{2}{|c|}{$\begin{array}{l}\text { (3) } \\
\text { Fuller Constant }\end{array}$} & \multicolumn{2}{|c|}{$\begin{array}{c}\text { (4) } \\
\text { Fuller Constant }\end{array}$} & \multicolumn{2}{|c|}{$\begin{array}{l}\text { (5) } \\
\text { Fuller Constant }\end{array}$} \\
\hline & 4 & 1 & 4 & 1 & 4 & 1 & 4 & 1 & 4 & 1 \\
\hline LogROpen & $\begin{array}{l}6.5 * * \\
(2.23)\end{array}$ & $\begin{array}{l}\mathbf{6 . 6 5}^{* *} \\
(2.47)\end{array}$ & $\begin{array}{l}\mathbf{5 . 1} * * \\
(2.3)\end{array}$ & $\begin{array}{l}\mathbf{5 . 1} * \\
(2.8)\end{array}$ & $\begin{array}{c}\mathbf{5 . 1 1} * * \\
(2.1)\end{array}$ & $\begin{array}{l}5.39 * * \\
(2.30)\end{array}$ & $\begin{array}{l}5.12 * * \\
(1.89)\end{array}$ & $\begin{array}{l}\mathbf{5 . 5} * * \\
(2.02)\end{array}$ & $\begin{array}{l}5.99 * * \\
(1.87)\end{array}$ & $\begin{array}{c}\mathbf{6 . 3 3} * * \\
(2.01)\end{array}$ \\
\hline LogROpen*Log(Pop60) & $\begin{array}{c}-\mathbf{0 . 5 8} * * \\
(0.24)\end{array}$ & $\begin{array}{c}\mathbf{- 0 . 5 7 * *} \\
(0.27)\end{array}$ & $\begin{array}{l}-\mathbf{0 . 4 6 *} \\
(0.26)\end{array}$ & $\begin{array}{l}-0.44 \\
(0.31)\end{array}$ & $\begin{array}{c}-\mathbf{0 . 4 6} * * \\
(0.22)\end{array}$ & $\begin{array}{l}-\mathbf{0 . 4 6 *} \\
(0.25)\end{array}$ & $\begin{array}{c}-\mathbf{0 . 4 8} * * \\
(0.21)\end{array}$ & $\begin{array}{c}-\mathbf{0 . 5 1} * * \\
(0.21)\end{array}$ & $\begin{array}{c}-\mathbf{0 . 5 5} * * \\
(0.21)\end{array}$ & $\begin{array}{c}-\mathbf{0 . 5 8} * * \\
(0.21)\end{array}$ \\
\hline LogPop60 & $\begin{array}{l}\mathbf{4 . 8 2} * \\
(1.86)\end{array}$ & $\begin{array}{l}\mathbf{4 . 7 9} * * \\
(2.06)\end{array}$ & $\begin{array}{l}3.82 * \\
(1.99)\end{array}$ & $\begin{array}{l}\text { 3.79* } \\
(2.37)\end{array}$ & $\begin{array}{c}\mathbf{3 . 8 3} * * \\
(1.74)\end{array}$ & $\begin{array}{l}\text { 3.93** } \\
(1.91)\end{array}$ & $\begin{array}{l}\mathbf{3 . 8 4} * * \\
(1.55)\end{array}$ & $\begin{array}{l}\mathbf{4 . 1 1} * * \\
(1.65)\end{array}$ & $\begin{array}{l}4.44 * * \\
(1.57)\end{array}$ & $\begin{array}{c}4.67 * * \\
(1.67)\end{array}$ \\
\hline \multicolumn{11}{|l|}{ P-value Hypothesis } \\
\hline \multicolumn{11}{|l|}{ Other Controls } \\
\hline LogPCGDP60 & $\begin{array}{l}-0.54 \\
(0.33)\end{array}$ & $\begin{array}{l}-0.59 \\
(0.39)\end{array}$ & $\begin{array}{l}-0.98 \\
(0.37)\end{array}$ & $\begin{array}{l}-0.98 \\
(0.41)\end{array}$ & $\begin{array}{l}-0.98 \\
(0.37)\end{array}$ & $\begin{array}{l}-0.98 \\
(0.41)\end{array}$ & $\begin{array}{l}-1.04 \\
(0.34)\end{array}$ & $\begin{array}{l}-1.03 \\
(0.36)\end{array}$ & $\begin{array}{l}-0.75 \\
(0.32)\end{array}$ & $\begin{array}{l}-0.74 \\
(0.34)\end{array}$ \\
\hline RLAW & $\begin{array}{c}1.15 \\
(0.55)\end{array}$ & $\begin{array}{c}1.15 \\
(0.61)\end{array}$ & $\begin{array}{c}1.06 \\
(0.65)\end{array}$ & $\begin{array}{c}1.2 \\
(0.82)\end{array}$ & $\begin{array}{c}1.06 \\
(0.43)\end{array}$ & $\begin{array}{c}1.08 \\
(0.48)\end{array}$ & $\begin{array}{c}0.91 \\
(0.38)\end{array}$ & $\begin{array}{c}0.91 \\
(0.42)\end{array}$ & $\begin{array}{c}0.88 \\
(0.44)\end{array}$ & $\begin{array}{c}0.85 \\
(0.49)\end{array}$ \\
\hline Control Variables Used & & & Prim60 & Exp60 & & & Prim60, & b-Sahara & Sub- & hara \\
\hline Sample Size & & & & & & & & & & \\
\hline
\end{tabular}

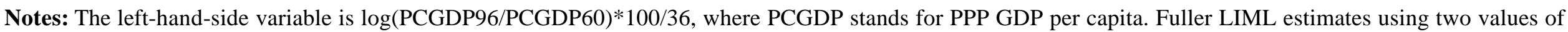

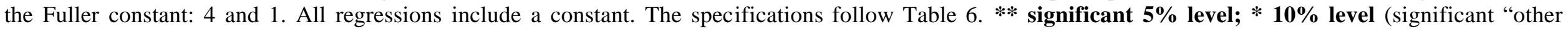
controls" are not marked). 